\title{
Chapter 21 \\ Regional Approaches to Improving Education in the Pacific and the Role of the University of the South Pacific
}

\author{
Chimi Thonden
}

Regional cooperation can offer much to the small dispersed island economies of the Pacific. The region contains some of the earliest regional organizations in Asia and the Pacific, with the fore-runner of the Secretariat of the Pacific Community established in 1947, the first meeting of leaders of the (now) Pacific Islands Forum in 1971, and the founding of the University of the South Pacific (USP) in 1968.

The USP one of two regional universities in the world, the other being in the Caribbean region. The USP jointly owned by the governments of the following 12 member countries: Cook Islands, Fiji, Kiribati, Marshall Islands, Nauru, Niue, Solomon Islands, Tokelau, Tonga, Tuvalu, Vanuatu, and Samoa. Campuses are located in all member countries, and the main campus is in Laucala, Fiji. The Alafua Campus in Samoa holds the School of Agriculture and Food Technology, and the Emalus Campus in Vanuatu holds the School of Law. The USP is governed by its own Council, which includes representatives of the member country governments, academic staff, students, community and business leaders, the Pacific Islands Forum Secretariat, the Secretariat of the Pacific Community, the American Council of Education, the Privy Council, Australia, and New Zealand.

The USP also operates 11 regional campuses based in Pacific island countries (PICs), which benefit from curricula, lecturers, administrative services, and support from the Fiji main campus. The network of campuses services a vast region of 33 million square kilometers of the Pacific Ocean, an area greater than three times the size of Europe. However, the total landmass area served corresponds to the country of Denmark. Populations of member countries range from Tokelau with 1500 people to Fiji with more than 900,000 people. (The total population of the USP region is approximately 1.3 million people.)

\footnotetext{
C. Thonden $(\varangle)$

Pacific Department, Asian Development Bank, Manila, Philippines

e-mail: cthonden@adb.org
} 


\title{
Expanding Access to Tertiary Education Through Enhanced Regional Campuses
}

\begin{abstract}
ADB's support to the USP began in 2009 with Regional Technical Assistance (RETA) 7282: Creation of the Pacific Information Super Highway, with the USP Network designed to support preparation of a multitranche financing facility loan to the USP. The \$19 million loan represented ADB's first and only nonsovereign regional education loan. The project supports the USP in expanding access to higher education in its 12 member PICs by improving physical environments and learning programs. The investment program focuses on (i) expanding regional campuses and in Kiribati and Solomon Islands, (ii) enhancing Information and Communication Technology (ICT)based distance learning programs, (iii) improving student services, and (iv) strengthening USP governance and management capacity. ${ }^{1}$ Improved access to quality higher education at the USP will contribute to human resource and skills development in the Pacific and will promote inclusive growth enabled by higher productivity and diversification of the region's economy.
\end{abstract}

In the Pacific, the gross enrollment ratio for higher education ranges from $10 \%$ in Fiji to 2-5\% in most other Pacific countries. Low enrollment is attributable to several factors including limited physical campus capacities, limited program coverage, and the perception of the quality of higher education programs available in the Pacific as insufficient. This has resulted in student desires to attend higher education outside the region, such as in Australia and New Zealand. This is largely unaffordable for the vast majority of students, especially those from low-income households, and only $5 \%$ of students seeking an overseas education can obtain government scholarships or private sponsorship. The governments of Kiribati and Solomon Islands view the value of in-country training as a better option to retaining students in their nations for tertiary education. The new expanded Kiribati campus, completed in 2015, already provides increased access to more than 3000 students doing preparatory, foundation, certificate, diploma, and degree studies at the USP. Similar works are soon to be underway for the Solomon Islands campus.

Under the umbrella of one university, regional cooperation and sharing of countrylevel lessons and good practice experiences are valuable to improving the quality of tertiary education across the region. The regional model of the university allows for greater efficiencies in small constrained economies, where resources may be more effectively spent on other priorities such as basic education. The contributing governments and higher education leaders believe that regional cooperation and cross-border collaboration are effective strategies for strengthening higher education in the region, as they are also owners of the USP.

\footnotetext{
${ }^{1}$ ADB. 2012. Report and Recommendation of the President to the Board of Directors: Multitranche Financing Facility: Higher Education in the Pacific Investment Program. Manila.
} 


\section{Facilitating Pacific Regional Education Initiatives}

USP also holds key regional roles in Human Resource Development (HRD) and in Information, Communications and Technology (ICT) as Chair of the Council of Regional Organizations of the Pacific (CROP) agency for HRD and for ICT. The USP's chair role on the CROP agency for HRD positions it well to facilitate the newly approved Pacific Regional Education Framework (PACREF). The Pacific Heads of Education Systems (PHES) developed, under the auspices of the Pacific Islands Forum and with the support of the Asian Development Bank (ADB) and Global Partnership for Education grant financing, the PACREF 2018-2030 program. Launched in October 2018, the PACREF outlines the region's education and training priorities and strategies, which stress a collaborative, Pacific-based approach to establishing a world-class human capital base.

Despite significant progress toward ensuring universal access to primary education, the quality of basic education remains a large challenge in the Pacific region. The results of the 2018 Pacific Islands Literacy and Numeracy Assessment (PILNA) revealed that in literacy, $47 \%$ of Year 4 students did not meet the expected minimum proficiency level in PILNA 2018, and 37\% of Year 6 students did not achieve it. In numeracy, $17 \%$ of students did not meet the minimum expected proficiency level both in Year 4 and Year $6 .^{2}$ These results indicate that education systems need to continue to address the needs of the region's lowest-performing students in order for young people to acquire the basic skills and foundations critical for further education and work.

Several factors constrain efforts to improve the quality of education in the Pacific. These include economic, geographic, and political issues that may hamper access to technology, resources, and policy support. Social and cultural constraints such as gender inequality, accessibility considerations for persons with disabilities, and the need to account for the rich language diversity in the Pacific affect access to education. Other challenges include weak teacher and principal preparation, exacerbated by high staff turnover, affect delivery of education services, poor coordination of complementary activities that hampers opportunities for further learning and enrichment, and gaps in data collection and analysis which limit monitoring, evaluation, and learning supposed to guide the development of policy and program interventions to improve the education sector and its outcomes. In recognition of these challenges, Pacific countries have affirmed their commitments to development goals and have fostered partnerships with development partners and neighboring countries through regional institutions and high-level forums. Responding to rising local and global demand for a qualified workforce, governments have started to integrate national education planning and budgeting, implement national policies for early childhood education, and push for curriculum reforms. Various improvement initiatives have also been undertaken at the school level. Governments also recognize that regional solutions can significantly enhance efforts to improve the quality of education largely because they create economies of scale that may not be possible when a country

\footnotetext{
${ }^{2}$ Pacific Island Literacy and Numeracy 2018 report.
} 
acts on its own. This enables more efficient use of scarce resources and encourages regional, as well as national institutions to coordinate and collaborate more closely, and, in the process, learn from one another.

\section{The Pacific Regional Education Framework ${ }^{3}$}

The PACREF has three phases which allow education ministers to conduct in-depth periodic reviews and allows for the time to obtain external financing. Phase 1 is being carried out in 2019-2022. Each phase is a 3-year rolling implementation process that requires annual updating that will help decision-makers to monitor available resources closely, as well as to ensure smooth transition between phases. Four regional agencies (the Educational Quality Assessment Program of the Pacific Community; the United Nations Educational, Scientific and Cultural Organization; the United Nations Children's Fund; and the University of the South Pacific through its School of Education and its Institute of Education) will support the program. Oversight functions will be shared among the following: (i) a PACREF Facilitating Unit under the Office of the University of the South Pacific Vice-Chancellor-to facilitate program operations of the four regional agencies as well as logistical and secretariat support; (ii) the Human Resources Development Working Group under the Council of Regional Organizations in the Pacific to coordinate implementation with the Facilitating Unit; (iii) a five-member steering committee composed of PHES members serving on a rotational basis - to represent the PHES on PACREF matters between PHES meetings; (iv) the PHES themselves - to ensure that the program addresses their respective countries' education needs and is being implemented smoothly at the country level; and (v) the education ministers of the Pacific Islands Forum member countries to meet every 2 years beginning in November 2020 to assess the PACREF's effectiveness and confirm the objectives and direction of the succeeding phases of the program.

There are four key policy areas in the PACREF, each with its own outcomes and strategies.

\section{High-quality Learning at All Levels of Education}

The PACREF seeks to develop inclusive, responsive curricula and programs that reflect Pacific values and culture, feature both cognitive and noncognitive development, and promote gender equality and innovation. Phase 1 involves the following activities: (i) production of tools that can be adapted to the national context for developing a curriculum with a Pacific identity and strengthening teacher competencies through standardized, regularly assessed, and continuous professional development opportunities; (ii) development of quality assurance frameworks at the

\footnotetext{
${ }^{3}$ Discussion of the PACREF and its components is based on ADB. July 2019. Pacific Economic Monitor, Policy Briefs: A regional approach to strengthening education in the Pacific. Manila. https://www.adb.org/sites/default/files/publication/514206/pem-july-2019.pdf.
} 
regional and national levels that cover external validation for qualifications and programs; (iii) establishment of quality learning environments at all levels through the appropriate pedagogy, new technologies, and enabling facilities and student care services; and (iv) improvement of learners' information management systems for monitoring student performance and better inform future education interventions. Later phases of PACREF will cover specialist programs for language acquisition, ICT-enabled learning, identifying and mitigating barriers to education, and ensuring that tertiary programs offer "future-focused" learning opportunities that meet labor market demand.

\section{Multiple, Accessible Learning Pathways and Modalities to Meet All Learners' Needs}

The PACREF will help create an enabling policy environment for school-level decision-making and flexibility to facilitate learning. It will support the adaptation of regional tools that can be to the national context to help improve the governance, financing, program development, and quality assurance of early childhood care and education. The program will also ensure seamless pathways between education levels and beyond, complemented by full participation of preschoolers and the most vulnerable learners (e.g., out-of-school and at-risk youths, girls, persons with disabilities, and remote communities). Phase 1 of the PACREF will help national education systems to mitigate the risks to transitions in education, as well as develop and implement technical and vocational education and training and other inclusive, alternative pathways for formal education and skills development.

\section{Learners Achieving Full Potential at All Levels}

The PACREF aims to improve learning outcomes at all levels, namely, proficiency in literacy and numeracy (particularly at the primary level) and participation and success rates. It will support access to early intervention programs; teacher training to improve literacy and numeracy instruction; and continuous, system-wide use of assessment for learning which is expected to help achieve these outcomes. Further, the PACREF will develop and implement programs to build life skills that take into account the Pacific context, while helping learners respond to twenty-first century challenges and opportunities. This will include capacity building in information and digital literacy, programs for career education and workplace readiness, and resource development to support programs that nurture noncognitive skills. Under this policy area, the program will engage social agencies and collaborate with relevant partners to establish child protection policies. It will also examine adult literacy to guide decision-making and policy development in this area.

\section{Competent and Qualified Teachers and School Managers}

The PACREF envisions schools staffed by teachers and school managers with the appropriate skills and certifications, the confidence of their communities, and access to a range of continued professional learning opportunities. Phase 1 will focus on improving understanding at all levels of education of teachers' professional standards and development, and regional application of performance management systems; 
and on strengthening preservice training and developing mechanisms to validate training programs across countries. It will support the development of regional standards, that will be complemented by opportunities for development, to help school managers better work with teachers toward meeting students' needs. Succeeding phases of the PACREF implementation will work on improving teachers' working conditions and remuneration, as well as establishing a code of ethics for teachers and school managers. It will support engagement and collaboration between the education system and community stakeholders, including teacher unions, and work to attract and retain quality teachers by marketing and advocating for the teaching profession. Partnerships with interested national education systems, and relevant development partners and regional agencies will be centered on these priority areas to help maintain proper focus of interventions and avoid redundant efforts.

By adopting a regional approach in close collaboration with national, regional, and multilateral partners, the PACREF 2018-2030 program seeks to deliver sustainable, high-quality education resources that can help improve learning outcomes in all Pacific countries. It responds to the Pacific governors' call at the 50th Annual Meeting of the ADB Board of Governors for more Pacific-based solutions and learning between developing member countries to address global education challenges.

ADB's support of the PACREF will help improve regional mechanisms for monitoring, evaluating, and designing education initiatives; enhance accessibility through e-learning; and support the exploration of options to further promote knowledge development and sharing in the Pacific. It will also provide a platform for policy dialogue, and a possible channel for additional resources in support of regional education initiatives.

\section{Promoting Open Distance and Flexible Learning for Quality Teaching and Learning}

There has been growing recognition of the importance of self-directed, resourcebased learning as a key driver of twenty-first-century human capabilities. Provision of e-learning resources, particularly more Pacific-contextualized teaching and learning resources, including adaptation of open education resources, can help leapfrog the Pacific region into adopting technology as key to inclusive growth and development. An ADB report recommended establishing a regional center to develop e-learning resources and provide curatorial services with appropriate human resources and technical facilities in the Pacific. ${ }^{4}$ The center can develop, collect, and coordinate the interchange of e-resources among the Pacific countries, and it should be organized regionally to leverage economies of scale and support national e-learning resource repositories. ${ }^{5}$ ADB will (i) support development of and adaptation of critically needed high-quality open education learning resources focused on Science, Technology,

\footnotetext{
${ }^{4}$ ADB. 2018. ICT for Better Education in the Pacific. Manila.

${ }^{5}$ ADB. 2018. Technical Assistance to the Region: Strengthening Education in the Pacific Region.
} 
Engineering, and Mathematics (STEM) subjects and literacy and numeracy spanning Kindergarten-Grade 12; (ii) develop and embed an intelligent tutoring system supported by AI research and innovations, in the e-learning resource design; and (iii) embed intelligent systems in the Learning Management System (LMS) platform to help teachers better manage student learning processes and outcomes.

With funding from the e-Asia Korea Knowledge Partnership Fund and High Level Technology Fund, ADB will work through the USP's Center for Flexible Learning (CFL) to house the development of quality e-learning resources in Fiji, which will be easily accessed and usable from all the Pacific countries' ministries of education. The USP again is well-positioned to play this role through the CFL and through the USP's role as CROP agency for ICT. The system will periodically replicate the repository data on all USP regional campuses. To maximize impact, the project will necessarily involve training teachers through teacher education programs, including the Fiji-based USP School of Education (SOE), which has a regional mandate, on strengthening teacher competencies in using and integrating ICT to support quality learning. The CFL will serve as the locus of repository and e-learning resources development under the project. The project will leverage previous ADB ICT regional infrastructure support to the USP to host the repository and can be supported to develop, curate, and distribute e-learning resources for the K-Grade 12 level. It will also leverage and complement New Zealand government support for the development of a regional platform and science e-resources. Currently, the USPnet serves only the university level of resources - in the future the repository may be expanded to host skill development and other related e-learning resources. The pilot will initially engage the USP CFL, the Fiji National University (the primary teacher education provider of teachers in Fiji), the USP SOE (to reach all regional campuses), and identified Fiji pilot schools and centers.

\section{Conclusion}

The deep educational challenges in the Pacific require the countries, institutions, and development partners to work together collaboratively to more effectively address the perennial challenges to improve countries' human capital bases. Over time, it is believed that the value of regional cooperation will be bear fruit, and that such approaches will help the region become more resilient and able to address the Pacific education challenges in a manner consistent with the Pacific interests.

Link to the presentation material: https://events.development.asia/materials/201 71213/university-south-pacific-21st-century-partnerships-skills. 


\section{References}

ADB. (2012). Report and recommendation of the President to the Board of Directors: Multitranche financing facility: Higher education in the Pacific investment program. Manila.

ADB. (2018a). ICT for better education in the Pacific. Manila.

ADB. (2018b). Technical assistance to the region: Strengthening education in the Pacific Region.

ADB Pacific Economic Monitor. (2019, July). https://www.adb.org/sites/default/files/publication/ 514206/pem-july-2019.pdf.

Pacific Island Literacy and Numeracy 2018 report.

The views expressed in this Chapter are those of the authors and do not necessarily reflect the views and policies of the Asian Development Bank (ADB) or its Board of Governors or the governments they represent.

ADB does not guarantee the accuracy of the data included in this Chapter and accepts no responsibility for any consequence of their use. The mention of specific companies or products of manufacturers does not imply that they are endorsed or recommended by ADB in preference to others of a similar nature that are not mentioned.

By making any designation of or reference to a particular territory or geographic area, or by using the term "country" in this Chapter, ADB does not intend to make any judgments as to the legal or other status of any territory or area.

This work is available under the Creative Commons Attribution 3.0 IGO license (CC BY 3.0 IGO) https://creativecommons.org/licenses/by/3.0/igo/. By using the content of this Chapter, you agree to be bound by the terms of this license. For attribution, translations, adaptations, and permissions, please read the provisions and terms of use at https://www.adb.org/terms-use\#openac cess.

This CC license does not apply to non-ADB copyright materials in this Chapter. If the material is attributed to another source, please contact the copyright owner or publisher of that source for permission to reproduce it. ADB cannot be held liable for any claims that arise as a result of your use of the material.

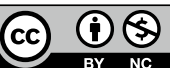

